\title{
Pengaruh Variasi Konsentrasi Sukrosa Terhadap Total Bakteri Asam Laktat, pH, Kadar Alkohol dan Hedonik Water Kefir Belimbing Manis (Averrhoa carambola)
}

\author{
Heni Rizqiati' ${ }^{1)}$, Sri Mulyani ${ }^{1)}$, dan Dhea Luthfia Ramadhanti ${ }^{1)}$ \\ ${ }^{1)}$ Program Studi Teknologi Pangan, Fakultas Peternakan dan Pertanian, \\ Universitas Diponegoro, Semarang, Indonesia \\ Email: henirizqi92@gmail.com
}

\begin{abstract}
ABSTRAK
Penelitian ini bertujuan untuk mengetahui pengaruh penambahan sukrosa dengan beberapa konsentrasi yang berbeda terhadap total bakteri asam laktat, nilai $\mathrm{pH}$, kadar alkohol, dan uji hedonik water kefir belimbing manis. Desain percobaan yang digunakan adalah Rancangan Acak Lengkap (RAL) dengan 5 perlakuan dan 4 kali ulangan, dengan perlakuan penambahan beberapa konsentrasi sukrosa $(0 \%, 3 \%, 6 \%, 9 \%$, dan 12\%). Belimbing yang digunakan adalah jenis belimbing manis dengan menggunakan grain water kefir sebanyak 5\% dan difermentasi selama 24 jam. Kualitas water kefir belimbing yang dianalisis yakni total bakteri asam laktat, nilai $\mathrm{pH}$, kadar alkohol dan kesukaan produk. Data parametrik yang diperoleh kemudian dianalisis dengan aplikasi SPSS 22.0 menggunakan Analysis of Variance (ANOVA) yang dilanjutkan dengan Duncan Multiple Range Test (DMRT), sedangkan data non parametrik dianalisis dengan uji Mann-Whitney yang dilanjutkan dengan uji Kruskall-Wallis. Hasil penelitian menunjukkan bahwa penambahan sukrosa dengan beberapa konsentrasi yang berbeda memberikan pengaruh nyata terhadap total bakteri asam laktat, kadar alkohol, nilai pH dan uji hedonik. Semakin tinggi konsentrasi sukrosa yang ditambahkan maka semakin tinggi total bakteri asam laktat, alkohol, dan hedonik serta menurunkan nilai $\mathrm{pH}$ pada produk, perlakuan terbaik terdapat pada perlakuan T3 dengan penambahan sukrosa sebanyak $9 \%$ yang menghasilkan total bakteri asam laktat sebesar 8,746, nilai $\mathrm{pH}$ sebesar 4,32, kadar alkohol sebesar 1,05\%, dan memiliki skor kesukaan sebesar 3,76.
\end{abstract}

Kata kunci : Alkohol; belimbing; pH; water kefir

The Effect of Variation Sucrose Concentration on Total Lactic Acid Bacteria, pH, Alcohol Content and Hedonic in Water Kefir from Starfruit (Averrhoa carambola)

\begin{abstract}
This research was to determine the effect of sucrose addition on total lactic acid bacteria, $\mathrm{pH}$ value, alcohol content, and hedonic test in water kefir from starfruit. The experimental design used was Completely Randomized Design (CRD) with 5 treatments and 4 replications, with treatment addition some concentration sucrose $(0 \%, 3 \%, 6 \%, 9 \%$, and $12 \%)$. Starfruit used is a type of sweet starfruit with a kefir water grain of $5 \%$ and fermented for 24 hours. Starfruit water kefir quality analyzed are total lactic acid bacteria, $\mathrm{pH}$ value, alcohol content and hedonic properties of the product. The resulted parametric data is then analyzed using Analysis of Variance (ANOVA) followed by Duncan Multiple Range Test (DMRT), while the non parametric data were analyzed using the Mann-whitney test followed by the Kruskall-wallis test. The results showed that the addition of sucrose with several different concentrations had a significant effect on total lactic acid bacteria, alcohol content, $\mathrm{pH}$ value and hedonic test. The higher sucrose concentration added the higher the resulted level on the total lactic acid bacteria, alcoholc and hedonic level also lower the $\mathrm{pH}$ value of the product, the best treatment is $\mathrm{T} 3$ with the addition of $9 \%$ sucrose which produces a total of 8,746 lactic acid bacteria, $\mathrm{pH}$ value of 4,32 , alcohol content of $1,05 \%$, and has a favorite score of 3,76 .
\end{abstract}

Keywords : Alcohol; starfruit; pH; water kefir

(Article History： Received 03-11-2020; Accepted 13-04-2021; Published 14-04-2021) 


\section{PENDAHULUAN}

Kefir adalah salah satu minuman probiotik yang memiliki rasa asam dan mengandung sedikit alkohol (Cahyani et al., 2019). Kefir termasuk kelompok pangan fungsional karena kefir dapat memberikan banyak manfaat bagi kesehatan tubuh. Kandungan gizi yang terdapat dalam kefir antara lain air $89,5 \%$, laktosa $4,5 \%$, protein $3,5 \%$, lemak $1,5 \%$, abu $0,6 \%$ dengan nilai $\mathrm{pH}$ berkisar antara 4,6 (Utomo et al., 2017). Kefir grains terdiri dari kumpulan bakteri asam laktat seperti (Lactobacillus kefir, Lactobacillus kefiranofaciens, Lactobacilli, Lactococci, Lactobacillus parakefir, dan Lactobacillus kefirgramum), khamir dan bakteri asam asetat. Water kefir merupakan salah satu jenis kefir yang terbuat dari bahan dasar berupa cairan yang mengandung gula seperti sari buah dan air gula yang kemudian ditambahkan butir kefir sehingga akan menghasilkan minuman probiotik dengan rasa yang asam dan mengandung sedikit alkohol dari hasil proses fermentasi (Lestari et al., 2018). Beberapa manfaat water kefir untuk kesehatan yaitu meningkatkan daya tahan tubuh, melancarkan proses pencernaan, menurunkan tekanan darah, mencegah alergi dan dapat menjadi antimikroba bagi mikroba pathogen yang akan memberikan dampak buruk bagi kesehatan (Schneedorf, 2012).

Belimbing manis (Averrhoa carambola 1.) merupakan komoditas tumbuhan yang berasal dari daerah tropis. Komposisi dalam 100 gram buah belimbing yaitu air 90 gram, gula total 3,5-11 gram, protein 0,75 gram dan serat 0,7 gram (Baswarsiati, 2017). Kandungan vitamin $C$ yang tinggi pada buah belimbing juga memungkinkan belimbing bermanfaat sebagai antioksidan yang dapat menangkal radikal bebas, meningkatkan daya tahan tubuh dan mencegah sariawan. Kandungan air yang relatif tinggi pada buah belimbing memungkinkan buah belimbing untuk diolah menjadi salah satu pangan fungsional yaitu water kefir. Kandungan air pada belimbing mencapai $90 \%$ dan serat sebanyak 0,9 gram per 100 gram belimbing (Wiradona \& Prasko, 2018). Salah satu faktor yang penting dalam proses fermentasi water kefir yaitu kecukupan nutrisi di dalam substrat. Nutrisi di dalam substrat yang berperan sebagai sumber pangan bagi kefir grain adalah gula sebagai sumber karbon. Sukrosa merupakan salah satu sumber karbon yang paling berpotensi untuk produksi selulosa dari bakteri secara fermentasi dan bukan hanya karena energinya dapat dikonversi dalam pembentukan glukosa dengan sukrosa sintase namun juga karena sukrosa secara komersial tersedia dalam jumlah yang cukup banyak dan harganya terjangkau (Wijayanti et al., 2012). Sukrosa terdapat di dalam jaringan tumbuhan tertentu seperti bit dan tebu sebagai cadangan makanan (Pontoh, 2013). Penambahan sukrosa maupun jenis gula lainnya pada pada produk water kefir juga dapat mempengaruhi kualitas dari kefir yang dihasilkan. Jumlah total asam dan khamir (Aristya et al., 2013), total bakteri asam laktat (Prastiwi et al., 2018) akan meningkat seiring dengan meningkatkan konsentrasi penambahan gula pada produk.

Penelitian terkait pemanfaatan buah belimbing manis menjadi produk fermentasi water kefir dengan penambahan sukrosa belum pernah dilakukan, sehingga perlu dilakukan uji karateristik produk seperti total bakteri asam laktat, $\mathrm{pH}$, kadar alkohol, serta kesukaan dari produk yang dihasilkan. Pada penelitian ini, dicoba untuk mengaplikasikan buah belimbing manis untuk diolah bahan dasar pembuatan water kefir. Penelitian ini bertujuan untuk mengetahui pengaruh penambahan sukrosa dengan beberapa konsentrasi yang berbeda terhadap total bakteri asam laktat, nilai $\mathrm{pH}$, kadar alkohol, dan uji hedonik water kefir belimbing manis. Informasi yang dihasilkan dalam penelitian ini diharapkan dapat menambah pemanfaatan buah belimbing manis dalam pengolahan pangan.

\section{METODE PENELITIAN}

Bahan utama yang dibutuhkan dalam penelitian ini yaitu buah belimbing manis, water kefir grain, sukrosa, air mineral, media de Man Rogosa and Sharpe Agar (MRSA), aquades, $\mathrm{NaCl}$ fisiologi $0,85 \%$. Alat yang digunakan pada penelitian ini yaitu toples, panci, sendok, blender, gelas ukur, pipet, thermometer, kompor, kain mori, plastik wrap, alumunium foil, gelas beaker, erlenmeyer, pH meter, corong pipet, piknometer, timbangan analitik, refrigerator, bunsen, inkubator, autoklaf, baskom, dan buret., cup, form uji hedonik, software SPSS versi 22.0 . 
Metode

Penelitian berlangsung selama periode Februari-Maret 2020. Penelitian meliputi proses pembuatan water kefir belimbing manis dan pengujian parameter. Parameter yang diuji meliputi total bakteri asam laktat (Rohman et al., 2019), nilai pH (Kinteki et al., 2018), kadar alkohol (Ginting et al., 2019), dan uji hedonik (Kania \& Judiono, 2017).

\section{Pembuatan Water Kefir Belimbing Manis}

Proses pembuatan water kefir buah belimbing manis ini mengacu pada penelitian Insani et al. (2018) dengan sedikit modifikasi yaitu pada bahan bakunya yang diganti dengan belimbing manis. Buah belimbing manis disortir untuk memilih kualitas terbaik, buah belimbing manis dicuci dan dipisahkan dari kulitnya serta dipotong. Setelah itu buah belimbing manis dihancurkan dengan menggunakan blender. Buah belimbing manis yang sudah dihancurkan kemudian ditambahkan air dengan perbandingan (1:2) dan kemudian disaring untuk mendapatkan sari buah belimbing manis. Perlakuan pertama (T0) yaitu dengan tanpa penambahan sukrosa, Perlakuan kedua (T1) yaitu dengan penambahan sukrosa 3\%, Perlakuan ketiga (T2) yaitu dengan penambahan sukrosa sebesar 6\%, Perlakuan keempat (T3) yaitu dengan penambahan sukrosa 9\%, Perlakuan kelima (T4) yaitu dengan penambahan sukrosa $12 \%$. Sari buah belimbing manis selanjutnya dilakukan pasteurisasi pada suhu $71^{\circ} \mathrm{C}$ selama 15 detik untuk memastikan bakteri pathogen mati. Sari buah belimbing manis kemudian dilakukan penurunan suhu hingga $37^{\circ} \mathrm{C}$. Sari buah belimbing manis yang telah dipasteurisasi ditambahkan grain water kefir sebanyak 5\% pada masing-masing perlakuan dan difermentasi secara anaerob pada suhu ruang selama $24 \mathrm{jam}$. Sampel water kefir yang sudah jadi kemudian disaring untuk memisahkan water kefir dan grain water kefir menggunakan saringan.

\section{Prosedur Analisis Total Bakteri Asam Laktat}

Pengujian total bakteri asam laktat dilakukan berdasarkan prosedur yang telah dilakukan Rohman et al. (2019) dengan cara sebanyak $1 \mathrm{ml}$ sampel water kefir diencerkan kedalam $9 \mathrm{ml} \mathrm{NaCl}$ fisiologi 0,85\%, larutan ini disebut pengenceran 10-1. Selanjutnya diambil $1 \mathrm{ml}$ dari sampel tersebut untuk diencerkan kembali ke dalam $9 \mathrm{ml} \mathrm{NaCl}$ fisiologi 0,85\%, larutan ini disebut 10-2. Perlakuan ini dilakukan terus menerus hingga mencapai pengenceran 10-6. Selanjutnya sampel sebanyak $1 \mathrm{ml}$ dari 3 pengenceran terakhir diambil lalu masing-masing sampel dimasukan ke dalam cawan petri dan dilakukan secara duplo. Kemudian cawan petri ditutup rapat agar tidak terjadi kontaminasi, kemudian sebanyak $15 \mathrm{ml} d e$ Man Ragosa and Shape Agar (MRSA) bersuhu $50^{\circ} \mathrm{C}$ dimasukan ke dalam cawan petri dengan cara membuka sedikit tutup cawan agar terhindar dari kontaminasi. Setelah itu cawan langsung digerakan di atas meja secara hati-hati dengan membentuk gerakan angka delapan supaya semua medium merata. Setelah medium padat, cawan diinkubasi dengan menggunakan inkubator bersuhu $37^{\circ} \mathrm{C}$ selama 24 jam dalam posisi cawan terbalik. Jumlah koloni dihitung pada cawan petri yang memiliki jumlah koloni sebanyak 30-300 koloni. Angkat total bakteri asam laktat dalam $1 \mathrm{ml}$ adalah dengan mengalikan jumlah koloni pada cawan petri dibagi dengan faktor pengenceran. Hasil analisis mikrobiologi dilaporkan dengan menggunakan Standard Plate Count (SPC).

\section{Prosedur Analisis Nilai pH}

Pengujian nilai $\mathrm{pH}$ dilakukan berdasarkan prosedur yang telah dilakukan Kinteki et al. (2018) dengan cara elektroda $\mathrm{pH}$ meter sebelumnya dikalibrasi ke dalam larutan buffer $\mathrm{pH}$ 4. Setelah dilakukan kalibrasi, Elektroda $\mathrm{pH}$ meter dicelupkan ke dalam sampel kemudian ditunggu hingga menunjukkan angka konstan dan $\mathrm{pH}$ sampel dapat dibaca.

\section{Prosedur Analisis Kadar Alkohol}

Pengujian kadar alkohol dilakukan berdasarkan prosedur yang telah dilakukan Ginting et al. (2019) dengan menggunakan metode destilasi. Proses destilasi diawali dengan penambahan $100 \mathrm{ml}$ sampel dan 100 $\mathrm{ml}$ aquadest ke dalam labu Kjeldahl, kemudian didestilasi hingga destilat mencapai $50 \mathrm{~mL}$. Penimbangan dilakukan terhadap piknometer kosong, piknometer berisi akuades, dan piknometer berisi destilat. Analisis kadar alkohol dilakukan menggunakan piknometer. Kadar alkohol diperoleh dengan mengkonversi berat jenis alkohol. Berat jenis alkohol ditentukan dengan rumus: Berat jenis alkohol

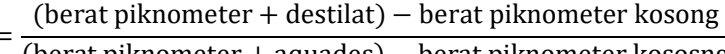




\section{Prosedur Analisis Uji Hedonik}

Pengujian hedonik dilakukan berdasarkan prosedur yang telah dilakukan Kania \& Judiono (2017). Uji hedonik dilakukan dengan menggunakan skala kesukaan terhadap formula water kefir yang dibuat. Panelis akan disajikan sampel-sampel yang akan dinilai yang dilengkapi dengan kuesioner dan kemudian panelis akan diminta untuk menilai sampel tersebut menurut skala berdasarkan tingkat kesukaannya. Dalam uji ini 25 panelis diminta untuk mencicipi sampel dan diantara masing-masing pencicipan sampel diharuskan mengkonsumsi air minum sebagai penetral, kemudian panelis diminta untuk memberikan penilaian tingkat kesukaan terhadap rasa, warna, aroma, dan overall, sampel dengan menggunakan 5 tingkat skala hedonik. Dimulai dari sangat tidak suka $(=1)$, tidak suka $(=2)$, suka $(=3)$, dan sangat suka $(=4)$.

\section{Analisis Data}

Analisis dilakukan menggunakan software SPSS 25.0 for Mac pada taraf nyata $95 \%(\mathrm{p} \leq 0,05)$. Data hasil uji total bakteri asam laktat, nilai $\mathrm{pH}$, dan kadar alkohol dianalisis statistik dengan ANOVA (Analysis of Varians). Apabila terdapat pengaruh nyata maka dilakukan uji lanjutan menggunakan uji Wilayah Berganda Duncan. Data hasil uji hedonik (kesukaan) dianalisis statistik dengan Kruskal Wallis dan dilanjut uji MannWhitney.

\section{HASIL DAN PEMBAHASAN}

\section{Total Bakteri Asam Laktat}

Hasil pengujian total bakteri asam laktat, nilai $\mathrm{pH}$, kadar alkohol, dan uji hedonik pada water kefir belimbing manis dengan penambahan variasi sukrosa dapat dilihat pada Tabel 1. Berdasarkan Tabel 1 dapat diketahui bahwa penambahan sukrosa pada water kefir belimbing manis memberikan pengaruh nyata terhadap total bakteri asam laktat water kefir belimbing manis pada perlakuan T0 dengan kosentrasi sukrosa sebesar $0 \%$ berbeda nyata $(\mathrm{P}<0,05)$ dengan water kefir belimbing manis perlakuan T3 dengan konsentrasi sukrosa sebesar 9\%, dengan rata-rata total bakteri asam laktat sebesar 8,746. Total bakteri asam laktat terendah terdapat pada perlakuan T0 atau tanpa ada penambahan sukrosa yaitu sebesar 7,35. Peningkatan total bakteri asam laktat dari T0 (tanpa penambahan sukrosa) menuju T1 (3\%), T2 (6\%), T3 (9\%) dan T4 (12\%) yaitu sebesar 7,35, 7,517, 7,742, 8,746, dan 7,815. Hal ini menunjukkan bahwa penambahan sukrosa dengan konsentrasi yang berbeda menghasilkan total bakteri asam laktat yang berbeda juga. Hal ini sesuai dengan pendapat Prastiwi et al. (2018) yang menyatakan bahwa konsentrasi gula dan waktu fermentasi dapat berpengaruh nyata terhadap pertumbuhan bakteri asam laktat. Penurunan jumlah total bakteri asam laktat pada water kefir belimbing manis dengan perlakuan T4 dapat disebabkan karena konsentrasi sukrosa yang ditambahkan terlalu tinggi, sehingga dapat menyebabkan media fermentasi menjadi hipertonik dan menyebabkan bakteri asam laktat mati. Hal ini sesuai dengan pendapat Pradipta et al. (2020) yang menyatakan bahwa peningkatan konsentrasi sukrosa akan merubah lingkungan pertumbuhan bakteri sehingga akan menurunkan total bakteri asam laktat.

Peningkatan dan penurunan jumlah bakteri asam laktat sangat dipengaruhi oleh jumlah nutrisi (gula), sinergi antar bakteri asam laktat dan proses fermentasi (waktu fermentasi dan suhu fermentasi). Sukrosa yang ditambahkan pada water kefir belimbing manis berperan sebagai sumber energi bagi bakteri asam laktat untuk tumbuh. Hal ini sesuai dengan pendapat Rumeen et al. (2018) yang menyatakan bahwa sukrosa berpengaruh sebagai sumber energi dalam pertumbuhan bakteri asam laktat. Sukrosa yang ditambahkan pada water kefir belimbing manis juga akan dimanfaatkan oleh khamir dan bakteri asam asetat untuk pertumbuhannya. Hal ini sesuai dengan pendapat Fiorda et al. (2017) yang menyatakan bahwa selama fermentasi sukrosa tidak hanya dimanfaatkan oleh bakteri asam laktat tetapi juga dimanfaatkan oleh ragi dan bakteri asam asetat untuk melakukan metabolisme. Meningkatnya total bakteri asam laktat juga dapat meningkatkan jumlah asam laktat yang dihasilkan, dimana semakin tinggi asam laktat pada produk maka semakin rendah $\mathrm{pH}$ yang dihasilkan (Kumalasari et al., 2013).

\section{Nilai pH}

Berdasarkan Tabel 1 dapat diketahui bahwa penambahan sukrosa pada water kefir belimbing manis dengan konsentrasi yang berbeda menghasilkan perbedaan yang 
signifikan $(\mathrm{P}<0,05)$ terhadap nilai $\mathrm{pH}$ pada perlakuan T0 (tanpa penambahan sukrosa), T1 (3\%), T2 (6\%), T3(9\%), T4 (12\%). Nilai pH terendah terdapat pada pelakuan T3 (9\%) sebesar 4,32 dan nilai $\mathrm{pH}$ tertinggi terdapat pada perlakuan T0 (tanpa penambahan sukrosa) sebesar 4,77. Hal ini menunjukkan bahwa mikroba pada water kefir dengan perlakuan T3 tumbuh dengan maksimal karena dapat memecah sukrosa dengan baik. Hal ini sesuai dengan pendapat Hardini et al. (2018) yang menyatakan bahwa bakteri asam laktat pada konsentrasi sukrosa 9\% akan memecah ketersediaan sukrosa secara optimal dan mengubahnya menjadi asam laktat, sehingga akan mengakibatkan adanya penurunan nilai $\mathrm{pH}$ dikarenakan hasil asam laktat yang meningkat. Nilai $\mathrm{pH}$ pada penambahan sukrosa $12 \%$ mengalami kenaikan. Hal ini dikarenakan penambahan sukrosa yang terlalu banyak juga dapat mempengaruhi pertumbuhan bakteri asam laktat karena konsentrasi sukrosa yang terlalu tinggi dapat mengakibatkan terjadinya tekanan osmotik. Hal ini sesuai dengan pendapat Taufik \& Maruddin (2020) yang menyatakan bahwa sukrosa yang ditambahkan pada konsentrasi tertentu dapat memungkinkan terjadnya tekanan osmotik pada media fermentasi sehingga akan mempengaruhi pertumbuhan mikroorganisme tertentu. Nilai $\mathrm{pH}$ pada water kefir dengan perlakuan $\mathrm{T} 0$ memiliki nilai $\mathrm{pH}$ yang paling tinggi, karena water kefir dengan perlakuan T0 tidak ada penambahan sukrosa, sehingga nutrisi yang terdapat pada media fermentasi tidak cukup untuk bakteri asam laktat dalam menghasilkan asam laktat. Hal ini sesuai dengan pendapat Yurliasni et al. (2019) yang menyatakan bahwa bakteri asam laktat akan tumbuh secara optimal ketika ketersediaan nutrisinya dapat terpenuhi, sehingga akan tumbuh dan menghasilkan jumlah sel yang tinggi. Selain itu karena kandungan nutrisi pada media fermentasi yang rendah menyebabkan lambatnya fermentasi dan meningkatnya pH (Laureys et al., 2018).

Tabel 1. Hasil Pengujian Total Bakteri Asam Laktat, Nilai pH, Kadar Alkohol, dan Uji Hedonik

\begin{tabular}{|c|c|c|c|c|c|}
\hline \multirow{2}{*}{ Parameter Uji } & \multicolumn{5}{|c|}{ Rata-Rata Perlakuan } \\
\hline & T0 & T1 & T2 & T3 & T4 \\
\hline $\begin{array}{l}\text { Total BAL } \\
(\log \mathrm{CFU} / \mathrm{ml})\end{array}$ & & $7,517 \pm 0,067^{\mathrm{ab}}$ & $7,742 \pm 0,052^{b}$ & $8,746 \pm 0,222^{c}$ & $7,815 \pm 0,019^{b}$ \\
\hline Nilai pH & & $4,63 \pm 0,012^{\mathrm{d}}$ & & & $4,52 \pm 0,008^{\mathrm{b}}$ \\
\hline Kadar Alkohol & $0,23 \pm 0,034^{\mathrm{a}}$ & $0,33 \pm 0,057^{\mathrm{a}}$ & $0,46 \pm 0,053^{\mathrm{b}}$ & $1,05 \pm 0,115^{\mathrm{c}}$ & $0,63 \pm 0,085^{\mathrm{d}}$ \\
\hline
\end{tabular}

*Data ditampilkan sebagai rerata dari 4 ulangan \pm standar deviasi

*Superscript huruf kecil yang berbeda pada baris yang sama menunjukkan berbeda nyata $(\mathrm{P}<0,05)$

*T0, T1, T2, T3, T4 masing-masing adalah kosentrasi sukrosa tanpa penambahan sukrosa (0\%), 3\%, 6\%, $9 \%$, $12 \%$

\section{Kadar Alkohol}

Berdasarkan Tabel 1 dapat diketahui bahwa penambahan sukrosa pada water kefir belimbing manis memberikan pengaruh nyata terhadap kadar alkohol. water kefir belimbing manis pada perlakuan T0 (tanpa penambahan sukrosa) berbeda nyata $(\mathrm{P}<0,05)$ dengan perlakuan T3 (9\%) dengan rata-rata kadar alkohol sebanyak $1,05 \%$. Water kefir belimbing manis dengan kadar alkohol terendah yaitu terdapat pada perlakuan T0 (tanpa penambahan sukrosa) dengan kadar alkohol sebanyak $0,23 \%$. Kadar alkohol pada perlakuan T3 berbeda nyata dengan kadar alkohol T0, T1, T2 dan T4. Hal ini menunjukkan bahwa penambahan sukrosa memiliki pengaruh pada kadar alkohol water kefir belimbing manis. Hal ini sesuai dengan pendapat Insani et al. (2018) yang menyatakan bahwa penambahan gula pasir dapat memberi pengaruh terhadap kadar alkohol minuman fermentasi. Kadar alkohol yang dihasilkan pada water kefir belimbing manis pada perlakuan T0-T3 mengalami kenaikan dan pada perlakuan T3-T4 mengalami penurunan. Peningkatan kadar alkohol ini dikarenakan adanya aktivitas dari mikroba yang memecah sukrosa menjadi alkohol. Hal ini sesuai dengan pendapat Fatimah et al. (2013) yang menyatakan bahwa peningkatan kadar alkohol tersebut adalah hasil aktivitas yang dilakukan oleh mikroba yang merubah gula menjadi etanol. Penurunan kadar alkohol tersebut juga dapat disebabkan karena khamir memiliki batas kemampuan dalam memproduksi alkohol pada saat fermentasi. Hal ini sesuai 
dengan pendapat Simanjuntak et al. (2017) yang menyatakan bahwa khamir yang digunakan saat fermentasi memiliki kapasitas produksi alkohol tertinggi pada konsentrasi optimum tertentu.

\section{Uji Hedonik} Rasa

Hasil uji statistik hedonik rasa, aroma, sensasi soda, dan overall water kefir belimbing manis dengan penambahan sukrosa dapat dilihat pada Tabel 2. Hasil uji hedonik terhadap rasa water kefir belimbing manis berkisar antara 1,44 hingga 3,56. Berdasarkan Tabel 2 dapat dike tahui bahwa terdapat perbedaan yang signifikan antara $\mathrm{T} 0, \mathrm{~T} 3$ dan T4 dengan T1 dan T2. Hal ini menunjukkan bahwa penambahan sukrosa dengan beberapa konsentrasi yang berbeda dapat berpengaruh terhadap tingkat kesukaan kesukaan rasa water kefir belimbing manis. Rasa asam yang terdapat pada water kefir berasal dari starter yang digunakan pada saat proses fermentasi karena mengandung bakteri asam laktat dan khamir. Hal ini sesuai dengan pendapat Rahayu et al. (2020) yang menyatakan bahwa starter yang digunakan pada pembuatan kefir mengandung BAL dan yeast. Bakteri asam laktat yang ada pada starter tersebut yang akan menghasilkan rasa asam, karena bakteri asam laktat memiliki peran dalam pembentukan asam laktat. Berdasarkan Tabel. 2 dapat diketahui bahwa panelis tidak menyukai water kefir belimbing manis dengan perlakuan T0 (tanpa penambahan sukrosa). Hal ini dikarenakan water kefir belimbing manis dengan perlakuan T0 memiliki rasa yang sedikit asam, namun juga memiliki rasa yang hambar. Panelis sangat menyukai water kefir belimbing manis dengan perlakuan T4 (12\%) karena water kefir dengan perlakuan T4 (12\%) memiliki rasa agak asam dan dominan rasa manis. Hal ini sesuai dengan pendapat Prastiwi et al. (2018) yang menyatakan bahwa adanya penambahan bahan pemanis seperti sukrosa, glukosa dan fruktosa sebesar $8 \%$ atau lebih akan mempengaruhi produksi asam laktat sebagai penghasil cita rasa kefir.

\section{Aroma}

Hasil uji hedonik terhadap aroma water kefir belimbing manis berkisar antara 1,24 hingga 3,72. Berdasarkan Tabel 2 dapat diketahui bahwa terdapat perbedaan yang signifikan antara T0, T1 dan T3 dengan T2 dan T4. Water kefir belimbing manis memiliki aroma seperti tape dan sedikit aroma belimbing. Hal ini sesuai dengan pendapat Sholichah et al. (2019) yang menyatakan bahwa kefir memiliki aroma khas seperti tape yang berasal dari hasil metabolisme mikroba yang terdapat pada biji kefir. Berdasarkan Tabel 2 dapat diketahui bahwa panelis tidak menyukai water kefir belimbing manis dengan perlakuan T0 (tanpa penambahan sukrosa) dikarenakan water kefir belimbing manis dengan perlakuan T0 memiliki aroma khas kefir yang tidak terlalu kuat. Panelis sangat menyukai water kefir belimbing manis dengan perlakuan T3 (9\%). Hal ini dikarenakan water kefir belimbing manis dengan perlakuan T3 (9\%) memiliki aroma water kefir yang cukup kuat. Aroma khas water kefir yang cukup kuat pada perlakuan T3 dapat dipengaruhi karena kandungan senyawa yang ada pada water kefir belimbing manis. Hal ini sesuai dengan pendapat Lestari et al. (2018) yang menyatakan bahwa jumlah senyawa-senyawa volatil yang terkandung di dalam kefir seperti asam laktat, asam asetat, dan alkohol akan mempengaruhi ketajaman aroma kefir yang dihasilkan.

\section{Sensasi Soda}

Hasil uji hedonik terhadap sensasi soda water kefir belimbing manis berkisar antara 1,28 hingga 3,72. Berdasarkan Tabel 2 dapat diketahui bahwa terdapat perbedaan yang signifikan antara T0, T3, dan T4 dengan T1 dan T2. Hal ini menunjukkan bahwa penambahan konsentrasi sukrosa yang berbeda dapat memberi pengaruh terhadap sensasi soda yang dihasilkan pada water kefir belimbing manis. Hal ini sesuai dengan pendapat Cahyani et al. (2019) yang menyatakan bahwa meningkatnya penambahan jenis gula ke dalam media fermentasi akan memberikan nutrisi bagi khamir dan akan meningkatkan populasi sehingga kadar $\mathrm{CO}_{2}$ lebih tinggi dan sensasi soda yang dihasilkan akan bervariasi. Sensasi soda yang dihasilkan water kefir belimbing manis juga dipengaruhi oleh banyaknya khamir yang terdapat pada water kefir belimbing manis, karena sensasi soda merupakan hasil metabolisme khamir yang berupa karbondioksida (Laureys \& Vuyst, 2014). Berdasarkan Tabel 2 dapat diketahui bahwa panelis tidak menyukai water kefir belimbing manis dengan perlakuan T0 (tanpa penambahan sukrosa) dikarenakan water kefir 
belimbing manis dengan perlakuan T0 tidak memiliki sensasi soda seperti yang diharapkan oleh panelis. Panelis sangat menyukai water kefir belimbing manis dengan perlakuan T3 (9\%) dikarenakan water kefir belimbing manis dengan perlakuan T3 memiliki sensasi soda yang paling kuat, sehingga panelis menyukainya karena dapat memberikan efek segar pada saat dikonsumsi. Selain sensasi soda, water kefir dengan perlakuan T3 (9\%) memiliki buih dan gelembung udara yang paling banyak. Hal ini didukung oleh pendapat Kinteki et al. (2018) yang menyatakan bahwa kombinasi antara karbondioksida dan alkohol akan menghasilkan buih pada kefir.

Tabel 2. Skor Uji Hedonik Rasa, Aroma, Sensasi Soda, dan Overall pada Water Kefir Belimbing Manis

\begin{tabular}{lccccc}
\hline \multirow{2}{*}{$\begin{array}{c}\text { Atribut } \\
\text { Sensori }\end{array}$} & \multicolumn{5}{c}{ Perlakuan } \\
\cline { 2 - 6 } & T0 & T1 & T2 & T3 & T4 \\
\hline Rasa & $1,44 \pm 0,583^{\mathrm{a}}$ & $1,84 \pm 0,472^{\mathrm{b}}$ & $2,16 \pm 0,850^{\mathrm{b}}$ & $2,88 \pm 0,832^{\mathrm{c}}$ & $3,56 \pm 0,583^{\mathrm{d}}$ \\
Aroma & $1,24 \pm 0,435^{\mathrm{a}}$ & $1,80 \pm 0,577^{\mathrm{b}}$ & $2,24 \pm 0,663^{\mathrm{c}}$ & $3,72 \pm 0,458^{\mathrm{d}}$ & $2,52 \pm 0,822^{\mathrm{c}}$ \\
Sensasi Soda & $1,28 \pm 0,458^{\mathrm{a}}$ & $2,28 \pm 0,678^{\mathrm{b}}$ & $2,56 \pm 0,650^{\mathrm{b}}$ & $3,72 \pm 0,613^{\mathrm{c}}$ & $1,88 \pm 0,781^{\mathrm{d}}$ \\
Overall & $1,68 \pm 0,476^{\mathrm{a}}$ & $2,00 \pm 0,816^{\mathrm{a}}$ & $2,52 \pm 0,653^{\mathrm{b}}$ & $3,76 \pm 0,435^{\mathrm{c}}$ & $2,92 \pm 0,759^{\mathrm{b}}$ \\
\hline
\end{tabular}

Keterangan:

*Data ditampilkan sebagai rerata dari 4 ulangan \pm standar deviasi

* Superscript huruf kecil yang berbeda pada baris yang sama menunjukkan perbedaan nyata $(\mathrm{P}<0,05)$

*T0, T1, T2, T3, dan T4 = Konsentrasi sukrosa masing-masing : tanpa penambahan sukrosa $(0 \%), 3 \%, 6 \%$, $9 \%$, dan $12 \%$

*Angka yang diperoleh menginterpresentasikan bahwa angka 1 = Sangat tidak suka, 2 = Tidak suka, $3=$ Suka, 4 = Sangat suka.

\section{Keseluruhan (Overall)}

Berdasarkan Tabel 2 dapat diketahui bahwa penambahan sukrosa pada water kefir belimbing manis mempengaruhi terhadap penilaian keseluruhan (overall). Skor tertinggi terdapat pada water kefir belimbing manis dengan perlakuan T3 (9\%) dengan skor ratarata sebesar 3,76 dan skor terendah terdapat pada water kefir belimbing manis dengan perlakuan T0 (tanpa penambahan sukrosa) dengan skor rata-rata sebesar 1,68. Water kefir belimbing manis dengan perlakuan T3 dengan penambahan sukrosa sebesar $9 \%$ paling disukai karena memiliki aroma khas water kefir yang paling kuat dan memiliki sensasi soda yang paling terasa sehingga panelis menyukainya karena memberikan efek yang menyegarkan, namun panelis menyukai rasa water kefir belimbing manis dengan perlakuan $\mathrm{T} 4$ dengan penambahan sukrosa sebesar $12 \%$. Hal ini dikarenakan water kefir dengan perlakuan T4 dengan penambahan sukrosa sebesar $12 \%$ memiliki rasa yang manis. Namun, water kefir dengan perlakuan T3 dengan penambahan sukrosa sebesar $9 \%$ memiliki skor 3 (suka) untuk atribut rasa. Penelitian yang telah dilakukan oleh Mubin \& Elok (2015) tentang kefir nira siwalan menjelaskan bahwa kesukaan panelis dipengaruhi oleh senyawa kimia dan suhu yang selama proses fermentasi berlangsung akan membentuk asam-asam organik, sedangkan kesukaan panelis terhadap rasa akan dipengaruhi oleh suhu, senyawa kimia, konsentrasi dan interaksi antar komponen (Wardhana et al., 2016).

\section{KESIMPULAN}

Semakin tinggi konsentrasi sukrosa yang ditambahkan maka semakin tinggi total bakteri asam laktat, alkohol, dan hedonik serta menurunkan nilai $\mathrm{pH}$ pada produk. Perlakuan terbaik terdapat pada perlakuan $\mathrm{T} 3$ dengan penambahan sukrosa sebanyak 9\% yang menghasilkan total bakteri asam laktat sebesar 8,746, nilai $\mathrm{pH}$ sebesar 4,32, kadar alkohol sebesar $1,05 \%$, dan memiliki skor kesukaan sebesar 3,76. Data yang dihasilkan pada penelitian ini dapat digunakan sebagai referensi terkait pengaruh penambahan sukrosa terhadap kualitas dari produk water kefir yang dihasilkan.

Saran untuk penelitian selanjutnya yakni dibutuhkan pemahaman lebih lanjut terkait interaksi antara khamir dan kadar alkohol yang terbentuk dalam produk yang dihasilkan. 


\section{DAFTAR PUSTAKA}

Aristya, A.L., Legowo, A.M. \& Al-Baarri, A.N. 2013. Total Asam, Total Yeast, dan Profil Protein Kefir Susu Kambing Dengan Penambahan Jenis dan Konsentrasi Gula Yang Berbeda. Jurnal Pangan dan Gizi, 4(1): 39-48.

Baswarsiati. 2017. Karakteristik, Penciri dan Keunggulan Belimbing Varietas Karangsari Sebagai Varietas Unggul Asal Jawa Timur. Jurnal Ilmu-Ilmu Pertanian “AGRIKA", 11(2) : 191-205.

Cahyani, S.O., Dwiloka, B. \& Rizqiati, H. 2019. Perubahan Sifat Fisikokimia dan Mutu Hedonik Kefir Air Kelapa Hijau (Cocos nucifera L.) dengan Penambahan High Fructose Syrup (HFS). Jurnal Aplikasi Teknologi Pangan, 3(1): 96-103.

Fatimah., L.G., Febriana \& Lina, R.G. 2013. Kinetika Reaksi Fermentasi Alkohol dari Buah Salak. Jurnal Teknik Kimia USU, 2(2): 17-20.

Fiorda, F.A., Gilberto, V.D.M.P., Vanete, T.S., Sudip, K.R., Maria, G.B.P., Luciana, P.D.S.V. \& Carlor, R.S. 2017. Microbiological, Biochemical and Functional Aspects of Sugary Kefir. Food Microbiology, 66: 86-95.

Ginting, S.O., Bintoro, V.P. \& Rizqiati, H. 2019. Analisis Total BAL, Total Padatan Terlarut, Kadar Alkohol, dan Mutu Hedonik Pada Kefir Susu Sapi dengan Variasi Konsentrasi Sari Buah Naga Merah (hylocereus polyrhizus). Jurnal Teknologi Pangan, 3(1): 104-109.

Hardini, S., Pratama, Y. \& Rizqiati, H. 2018. Pengaruh Variasi Konsentrasi Sukrosa terhadap Total Bakteri Asam Laktat, Ph, Aktivitas Antioksidan dan Organoleptik Kefir Sari Buah Naga Merah (Hyloreceus polyrhizus). Jurnal Teknologi Pangan, 2(2): 76-83.

Insani, H., Rizqiati, H. \& Pratama, Y. 2018. Pengaruh Variasi Konsentrasi Sukrosa Terhadap Total Khamir, Total Padatan Terlarut, Kadar Alkohol dan Mutu Hedonik pada Water Kefir Buah Naga Merah (Hyloreceus polyrhizus). Jurnal Teknologi Pangan, 2(2): 90-95.

Kania, D.A. \& Judiono. 2017. Uji Kesukaan Es Krim Kefir Labu Kuning. Jurnal Riset Kesehatan, 9(1): 16-22.
Kinteki, G.A., Rizqiati, H. \& Hintono, A. 2018. Pengaruh Lama Fermentasi Kefir Susu Kambing Terhadap Mutu Hedonik, Total Bakteri Asam Laktat (BAL), Total Khamir, dan pH. Jurnal Teknologi Pangan, 3(1): 42-50.

Kumalasari, K.E.D., Legowo, A.M. \& AlBaarri, A.N. 2013. Total Bakteri Asam Laktat, Kadar Laktosa, pH, Keasaman, Kesukaan Drink Yogurt dengan Penambahan Ekstrak Buah Kelengkeng. Jurnal Aplikasi Teknologi Pangan, 2(4): 165-168.

Laureys, D. \& Luc De Vuyst. 2014. Microbial Species Diversity, Community Dynamic, and Metabolite Kinetics of Water Kefir Fermentation. Jurnal ASM, 80(8): 25642572.

Laureys, D., Maarten A., Peter V. \& Luc De Vuyst. 2018. Oxygen and Diverse Nutrient Influence The Water Kefir Fermentations Proccess. Food Microbiology, 73: 351-361.

Lestari, M.W., Bintoro, V.P. \& Rizqiati, H. 2018. Pengaruh Lama Fermentasi Terhadap Tingkat Keasaman, Viskositas, Kadar Alkohol, dan Mutu Hedonik Kefir Air Kelapa. Jurnal Teknologi Pangan, 2(1): 6-13.

Mubin, M.F. \& Elok, Z. 2015. Studi Aktivitas Antibakteri Kefir Teh Daun Sirsak (Annona Muricata linn.) dari Berbagai Merk Teh Daun Sirsak Dipasaran. Jurnal Pangan dan Agroindustri, 3(4): 16621672.

Pontoh, J. 2013. Penentuan Kandungan Sukrosa pada Gula Aren dengan Metode Enzimatik. Chemistry Prog. 6(1): 26-33.

Pradipta, A.A.Gd.T., Nociantiri, K.A. \& Permana, I.D.Gd.M. 2020. Pengaruh Konsentrasi Sukrosa Terhadap Karakteristik Minuman Sari Buah Sirsak (Annona muricata Linn) Terfermentasi dengan Isolate Lactobacillus sp. F213. Jurnal ITEPA, 9(2): 219-229.

Prastiwi, V.F., Bintoro, V.P. \& Rizqiati, H. 2018. Sifat Mikrobiologi, Nilai Viskositas dan Organoleptik Kefir Optima dengan Penambahan High Fructose Syrup (HFS). Jurnal Teknologi Pangan, 2(1): 27-32. 
Rahayu, W.E., Sa'diyah, S.H. \& Romalasari, A. 2020. Pengaruh Waktu Aplikasi dan Konsentrasi Penambahan Sari Buah Jambu Biji Merah (Psidium guajava $\mathrm{L}$.) Terhadap Kefir Susu Kambing. AGROMIX, 11(1): 1-8.

Rohman, A., Dwiloka, B. \& Rizqiati, H. 2019. Pengaruh Lama Fermentasi Terhadap Total Asam, Total Bakteri Asam Laktat, Total Khamir, dan Mutu Hedonik Kefir Air Kelapa Hijau (Cocos nucifera). Jurnal Teknologi Pangan, 3(1): 127-133.

Rumeen, S.F.J., Yelnetty, A., Tamasoleng, M. \& Lontaan, N. 2018. Penggunaan Level Sukrosa Terhadap Sifat Sensoris Kefir Susu Sapi. Jurnal Zootek, 38(1): 123130.

Schneedorf, J.M. 2012. Kefir D'aqua and Its Probiotic Properties. Intech. 53-78.

Sholichah, K., Bintoro, V.P \& Rizqiati, H. 2019. Analisis Karakteristik Kefir Optima dengan Menggunakan Bibit Praktis Terhadap Nilai $\mathrm{pH}$, Total BAL, Total Padatan Terlarut dan Organoleptik. Jurnal Teknologi Pangan, 3(2): 286-291.

Simanjuntak, M., Terip, K.K. \& Sentosa, G. 2017. Pengaruh Penambahan Gula Pasir dan Lama Fermentasi Terhadap Mutu Minuman Ferbeet (Fermented Beetboof). Jurnal Rekayasa Pangan dan Pertanian, 5(1): 96-101.
Taufik, M. \& Maruddin, F. 2020. Karakteristik Sensoris Produk Minuman Whey Fermentasi dengan Penggunaan Persentase Sukrosa. Jurnal Teknologi Industri Pertanian, 30(1): 36-42.

Utomo, B., Sugiarti, D.D. \& Awaludin, A.N. 2017. Sistem Informasi Kefir Susu Untuk Penyembuhan Jerawat Pada Wajah. Efektor, 4(2): 22-25.

Wardhana, K.P., Sumaryani, E. \& Sudiyono. 2016. Pengaruh Suhu dan Lama Penyimpanan Kulit Semangka (Citrullus vulgaris Schard) Terhadap Sifat Fisikokimia Minuman Sari Kulit Semangka. Jurnal Ilmu-Ilmu Pertanian, 10(1): 10-20.

Wijayanti, F., Kumalaningsih, S. \& Efendi, M. 2012. Pengaruh Penambahan Sukrosa dan Asam Asetat Glacial Terhadap Kualitas Nata dari Whey Tahu dan Substrat Air Kelapa. Jurnal Industrial, 1(2): 86-93.

Wiradona, I \& Prasko. 2018. Effectiveness Consuming Pineapple (Ananas comosus) And Star Fruit (Averrhoa carambola l) Toward Plaque Score. Jurnal Kesehatan Gigi, 5(1): 16-23.

Yurliasni, Hanum, Z. \& Hikmawan, R. 2019. Potensi Madu dalam Meningkatkan Kualitas Minuman Kefir. Jurnal Ilmu dan Teknologi Hasil Ternak, 14(1): 50-59. 